\title{
PERKUATAN SEISMIK STRUKTUR RANGKA BETON BERTULANG MENGGUNAKAN BREISING BAJA TIPE X DAN V TERBALIK
}

Made Sukrawa ${ }^{1}$, Ida Bagus Dharma Giri ${ }^{2}$, I Putu Deskarta ${ }^{3}$ Made Hendra Prayoga ${ }^{4}$

\begin{abstract}
Abstrak: Analisis struktur rangka terbuka beton bertulang dengan perkuatan breising baja telah dilakukan untuk membandingkan perilaku struktur rangka terbuka dengan struktur yang diperkuat breising. Tiga model struktur rangka terbuka 2D 3, 4 dan 5 lantai dibuat dan dianalisis dalam SAP2000 v17 dengan pendetailan menengah sesuai ketentuan SNI 1726:2002. Struktur rangka 3 bentang dengan panjang bentang $6 \mathrm{~m}$ dan tinggi tingkat 3,5 $\mathrm{m}$ dirancang dimensinya berdasarkan SNI 1726:2002, kemudian dianalisis kembali dengan pendetailan khusus sesuai ketentuan SNI 1726:2012. Setelah itu ditambahkan breising sebagai perkuatan seismik. Digunakan 2 tipe breising yaitu X dan V terbalik serta dianalisis dengan analisis konvensional dan konstruksi bertahap sesuai tahapan pelaksanaannya. Dari hasil analisis didapat bahwa, beberapa komponen struktur yang dianalisis dengan ketentuan SNI 1726:2012 mengalami tegangan berlebih. Setelah dilakukan perkuatan dengan breising, komponen tersebut memenuhi ketentuan kekuatan sesuai SNI 2847:2013 tentang Persyaratan Beton Struktural Untuk Bangunan Gedung. Disamping itu simpangan yang terjadi pada struktur rangka breising jauh lebih kecil dari simpangan struktur rangka terbuka dengan rasio masing-masing $0.08,0.12$ dan 0.18 untuk rangka breising $X 3,4$ dan 5 lantai dan masing-masing $0.07,0.11$ dan 0.16 untuk rangka breising $\mathrm{V}$ terbalik. Dengan analisis konstruksi bertahap simpangan struktur rangka breising X meningkat 14,38 \%, 13,62 \% dan 9,98 $\%$ dari hasil analisis konvensional untuk struktur 3, 4 dan 5 lantai. Untuk struktur dengan breising $\mathrm{V}$ terbalik simpangan meningkat masing-masing $15,83 \%, 14,29 \%$ dan $10,09 \%$.
\end{abstract}

Kata kunci: Analisis Konstruksi Bertahap, Breising Konsentrik, Perkuatan Seismik

\section{SEISMIC RETROFITTING OF RC FRAME WITH X AND INVERTED V STEEL BRACES}

Abstract: Analysis of reinforced concrete frame with steel braces has been done to compare the behavior of the open frame structure with reinforced concrete structure with steel braces. Three models of 2D open frame structure with 3, 4 and 5 floors were made and analyzed in SAP2000 v17 with intermediate detailing according to Indonesian Codes for Seismic Load (SNI 1726: 2002). 3-span frame structure with a span length of $6 \mathrm{~m}$ and level height of $3,5 \mathrm{~m}$ were designed according to SNI 1726: 2002, and then re-analyzed with special detailing according to New Indonesian Codes for Seismic Load (SNI 1726: 2012). After that, it was added with braces as seismic retrofitting. Two types of braces ( $\mathrm{X}$ and concentric inverted $\mathrm{V}$ ) were used in this study and analyzed with conventional analysis and stage construction analysis according to their stages of implementation. From the analysis results, several structure components that analyzed according to SNI 1726:2012 provitions were experience over-stressed. After retrofitted with steel braces, those components fulfill strength provition according to SNI 2847:2013 about structural concrete regulations for buildings. In addition to that, displacements that occurs on braced frame are smaller than displacements of the open frame structure with ratio of $0.08,0.12$, and 0.18 for X-brace frames with 3,4 , and 5 storey and $0.07,0.11$, and 0.16 for inverted-V brace. With staged construction analysis, displacements of $\mathrm{X}$-braced frame structure increased by $14.38 \%, 13.62 \%$, and $9.98 \%$ from the conventional analysis results for structure with 3,4 ,and 5 storey. For structure with inverted-V brace, displacements increased by $15.83 \%, 14.29 \%$, and $10.09 \%$.

Keywords: Stage Construction Analysis, Concentric Braces, Seismic Retrofitting

\footnotetext{
${ }^{1}$ Staf Pengajar Program Magister Program Magister Teknik Sipil, Program Pascasarjana, Universitas Udayana, Denpasar

${ }^{2}$ Staf Pengajar Program Magister Program Magister Teknik Sipil, Program Pascasarjana, Universitas Udayana, Denpasar

${ }^{3}$ Staf Pengajar Program Magister Program Magister Teknik Sipil, Program Pascasarjana, Universitas Udayana, Denpasar

${ }^{4}$ Alumni Jurusan Teknik Sipil, Fakultas Teknik Universitas Udayana
} 


\section{PENDAHULUAN}

Perubahan fungsi bangunan dan peraturan perencanaan merupakan alasan dilakukannya perkuatan terhadap struktur bangunan yang sudah berdiri (existing). Sebagai contoh, dengan ditetapkannya SNI 1726:2012 (SNI baru) sebagai revisi terhadap SNI-03-17262002 (SNI lama) tentang tata cara perencanaan ketahanan gempa untuk struktur bangunan gedung, maka beberapa wilayah di Indonesia mengalami peningkatan risiko yang dinyatakan dengan kategori disain seismik (KDS) A, B, C untuk risiko rendah sampai sedang dan D, E, F untuk risiko tinggi. Daerah Bali selatan berdasarkan SNI lama termasuk wilayah gempa $\mathrm{V}$ dengan risiko gempa sedang berubah menjadi KDS D. Perubahan ini berakibat pada peningkatan beban gempa rencana dan peningkatan syarat pendetailan struktur. Secara teori, struktur gedung yang dirancang menggunakan SNI lama akan mengalami tegangan berlebih (over stressed) jika menerima beban gempa rencana menurut SNI baru.

Ada beberapa metode yang sering digunakan untuk perkuatan struktur yang sudah berdiri (existing) antara lain penambahan komponen struktur (kolom, dinding), peningkatan kekuatan elemen struktur (pembesaran dimensi, penambahan lapisan berupa pelat baja (steel jacket) atau bahan komposit seperti FRP), pengurangan berat komponen non struktur dan kombinasi lainnya. Di negara-negara berkembang banyak menggunakan breising baja sebagai perkuatan terhadap struktur rangka yang telah berdiri karena sangat efektif meningkatkan kekakuan dan kekuatan struktur (Youssef et.al, 2007; Massumi and Absalan, 2013; Maheri, 2009). Salah satu metode perkuatan yang mudah dilakukan pada struktur yang sudah berdiri adalah penambahan breising berbentuk $\mathrm{V}$ (terbalik) dan X.

Penambahan breising pada struktur yang sudah berdiri akan memperkuat struktur dalam menahan beban lateral akibat gempa. Pada struktur yang sudah berdiri, struktur sudah mengalami deformasi akibat beban-beban yang bekerja (beban mati dan hidup). Pada saat dilakukan perkuatan struktur dengan penambahan breising baja, struktur sudah dalam keadaan berdeformasi. Sehingga analisis struktur setelah ditambahkan perkuatan breising harus memperhitungkan deformasi yang sudah terjadi. Salah satu metode analisis yang bisa digunakan adalah analisis konstruksi bertahap (stage construction analysis).

\section{TINJAUAN PUSTAKA}

Teknik Perkuatan Seismik

Metode perkuatan konvensional terdiri dari penambahan elemen struktur baru dan memperbesar dimensi elemen struktur. Penambahan dinding geser dan breising merupakan metode perkuatan yang paling banyak digunakan, karena kedua metode tersebut lebih efektif, relative mudah dan biayanya lebih kecil dibandingkan pembesaran dimensi kolom dan balok. Perkuatan rangka dengan breising baja merupakan perkuatan yang memiliki daktilitas yang tinggi. Desain struktur dengan perkuatan breising baja diterapkan untuk menahan sebagian besar beban lateral yang terjadi pada struktur. Hal ini akan mengurangi gaya - gaya dalam yang terjadi pada balok dan kolom.

\section{Perkuatan Struktur dengan Breising Baja}

Penambahan breising baja pada struktur rangka merupakan salah satu metode untuk meningkatkan kekuatan dan kekakuan sistem struktur. Perkuatan struktur dengan breising baja memiliki beberapa keuntungan, yaitu waktu pengerjaan yang singkat dan tidak memberi pengaruh signifikan pada berat struktur. Pemasangan breising baja dapat dilakukan pada bagian luar (eksterior) gedung, sehingga tidak mengganggu aktifitas di dalam struktur tersebut. Dalam pelaksaan, breising baja juga mudah diangkut ke tingkat atas.

Tipe breising yang umum digunakan adalah breising konsentrik. Sistem rangka batang breising konsentrik (SRBK) merupakan sistem struktur untuk menahan beban lateral dengan kekakuan struktur yang tinggi, karena adanya breising diagonal yang berfungsi untuk menahan beban lateral pada struktur. Elemen breising diharapkan mampu berdeformasi inelastik yang besar tanpa terjadi kehilangan yang signifikan pada kekuatan dan kekakuan struktur. Pada sistem struktur SRBK, kategori struktur dibagi menjadi dua yaitu Sistem Rangka Breising Konsentrik Biasa (SRBKB) dan Sistem Rangka Breising Konsentrik Khusus (SRBKK) (AISC, 2012). 
Perbedaan dari kedua sistem tersebut terletak pada deformasi yang diharapkan. Pada SRBKB, diharapkan dapat mengalami deformasi inelastik secara terbatas apabila dibebani oleh gaya-gaya yang berasal dari beban gempa rencana. Sedangkan pada SRBKK struktur diharapkan dapat berdeformasi inelastik cukup besar akibat gaya gempa rencana. SRBKK memiliki daktilitas yang lebih tinggi dibandingkan SRBKB dan penurunan kekuatan lebih kecil pada saat terjadi tekuk pada breising tekan (AISC, 2012).

Penelitian tentang kinerja seismik rangka breising baja yang diperkuat dengan breising baja konsentrik telah dilakukan oleh Youssef et al (2007) dengan membuat dan membebani 2 model struktur dengan skala yang diperkecil sebesar 2/5 dari aslinya. Model 1 rangka momen yang dirancang sesuai dengan persyaratan SRPMM, sedangkan model 2 rangka momen dengan breising baja $X$ dengan pendetailan biasa.

Kedua model dibebani siklik sampai runtuh dan hubungan antara beban dengan deformasi serta pola retak dicatat. Data-data pengujian disajikan pada Tabel 1.

Tabel 1. Data Model untuk Pengujian

\begin{tabular}{|l|l|l|}
\hline & Balok & Kolom \\
\hline Model 1 & $140 \times 160 \mathrm{~mm}$ & $140 \times 160 \mathrm{~mm}$ \\
\hline $\begin{array}{l}\text { Tulangan } \\
\text { memanjang }\end{array}$ & $2 \mathrm{M} 10$ & $4 \mathrm{M} 15$ \\
\hline Sengkang & $Ф 6-35$ & $Ф 6-35$ \\
\hline Model 2 & $140 \times 160 \mathrm{~mm}$ & $140 \times 160 \mathrm{~mm}$ \\
\hline $\begin{array}{l}\text { Tulangan } \\
\text { memanjang }\end{array}$ & $2 \mathrm{M} 10$ & $4 \mathrm{M} 10$ \\
\hline Sengkang & $Ф 6-70$ & $Ф 6-70$ \\
\hline Breising & \multicolumn{2}{|c|}{ L25x25x3,2 } \\
\hline
\end{tabular}

Diadaptasi dari: Youssef et.al (2007)

Hasil pengujian menunjukan hubungan beban dan rasio simpangan seperti pada Gambar 1. Kurva menunjukan dari rangka mulai retak hingga keadaan ultimit. Rangka breising mampu menahan hingga $140 \mathrm{kN}$ dan rangka momen hanya mampu menahan $55 \mathrm{kN}$. Untuk rangka breising beban retak $90 \mathrm{kN}$ dan beban pada saat mencapai leleh $105 \mathrm{kN}$. Sedangkan untuk rangka momen beban retak $30 \mathrm{kN}$ dan beban leleh $37,5 \mathrm{kN}$. Hasil penelitian juga menunjukan bahwa, rangka breising jauh lebih kuat dan kaku dibandingkan dengan rangka momen dengan pendetailan khusus untuk seismik. Rangka breising yang dirancang dengan faktor reduksi beban yang sama dengan faktor reduksi untuk SRPMM. Perencanaan rangka breising baja pada rangka breising bisa dilakukan dengan cara konvensional tanpa pendetailan khusus.

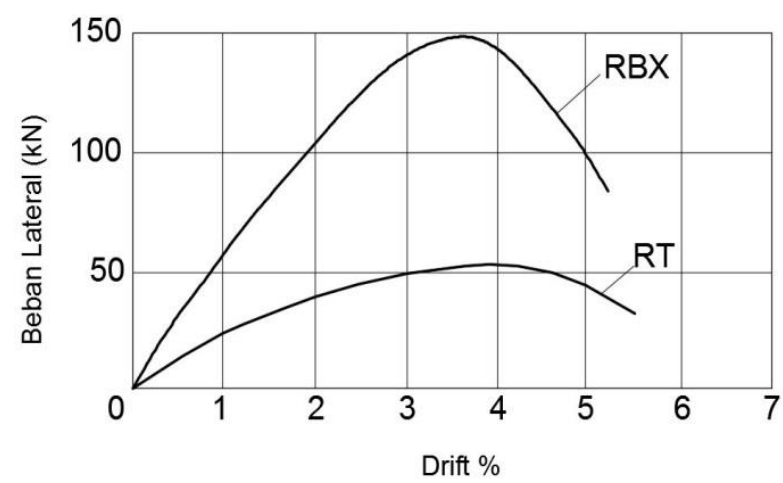

Gambar 1. Hubungan Beban dan Rasio Simpangan

Diadaptasi dari: Youssef et.al (2007)

Maheri (2009) melakukan penelitian pada beberapa parameter respon seismik seperti uji pushover, uji siklik dan faktor perilaku seismik, kemudian ditambah koneksi kuat lebih dan alat pelepas tekan. Pada pengujian uji pushover dibuat 4 model yang diskala 1:3,2 yaitu 2 model tanpa breising dan 2 model dengan breising dengan semua unit rangka daktail. Hasil dari pengujian pushover menunjukkan bahwa, terjadi 3,5 kali peningkatan untuk kapasitas beban lateral. Peningkatan juga terjadi pada kekakuan sampai breising tersebut mengalami kegagalan atau tekuk. Penggunaan breising mengakibatkan 5 kali peningkatan kekakuan yang mengindikasi penyerapan energi yang besar. Untuk daktilitas, kuat lebih dan faktor kinerja menunjukan bahwa breising lebih cocok untuk desain berdasarkan kekuatan daripada desain daktail.

Penelitian tentang uji siklik dilakukan dengan memodel rangka momen beton bertulang dengan rangka breising $\mathrm{X}$ beton bertulang yang di skala $2 / 5$. Penulangan untuk rangka momen yaitu 4M10 untuk balok dan 4M15 untuk kolom dengan sengkang $35 \mathrm{~mm}$. Sedangkan breising menggunakan 4M10 dengan sengkang $70 \mathrm{~mm}$. Pada sistem breising 
dibuat 2 jenis tipe breising yaitu FX1 penampang sudut ganda $2 \mathrm{~L} 25 \times 25 \times 32 \mathrm{~mm}$ dan FX2 penampang kanal C 3x35 mm. Uji siklik dilakukan dengan memberi beban gravitasi menggunakan hydraulik. Dari hasil tes menunjukan bahwa, untuk rangka breising FX1 dan FX2 memiliki kekakuan 2 kali lipat dari kekakuan lateral rangka pemikul momen. Tetapi kekakuan akan sama seperti rangka pemikul momen setelah terjadi tekuk. Penambahan breising menyebabkan penurunan daktilitas dari rangka daktail, tetapi penurunan daktilitas tersebut tidak mempengaruhi kapasitas kehilangan energi dari rangka.

Untuk meningkatkan daktilitas dan mempertahankan kekuatan dan kekakuan dari rangka breising, penambahan breising pada setiap sudut dan alat pelepas tekan di rekomendasikan berdasarkan hasil tes. Analisis dilakukan dengan membuat 4 model rangka untuk dites pushover yaitu 2 rangka tanpa breising dan 2 dengan breising sudut. Dari tes tersebut didapatkan bahwa kapasitas ultimit dari breising sudut lebih besar 2,5 kali dari rangka tanpa breising. Kurva pushover juga menunjukan peningkatan daktilitas rangka dengan breising sudut dibandingkan breising X. Alat pelepas tekan dipasang pada batang breising untuk melepas gaya tekan. Dibuat 2 benda uji dengan alat tersebut kemudian dibandingkan dengan 2 benda uji tanpa breising dan 2 dengan breising X. Pada degradasi kekakuan dengan penggunaan alat pelepas tekan, dapat meminimalkan keretakan pada rangka beton bertulang. Pada penggunaan alat pelepas tekan, terjadi peningkatan kapasitas kehilangan energi ke level yang lebih tinggi dari rangka tanpa alat pelepas tekan. Pada daktilitas pengaruh alat pelepas tekan mampu meningkatkan daktilitas pada rangka breising.

\section{Analisis Konstruksi Bertahap}

Konstruksi bertahap (stage construction analysis) merupakan bagian dari analisis statis nonlinier yang menganalisa struktur dalam beberapa fase tingkat/tahap (Analysis Reference Manual SAP2000, 2002). Ide dasar dari analisis ini adalah pada tahap awal kondisi awal struktur adalah nol. Semua elemen belum terbebani dan belum terjadi lendutan. Untuk tahapan analisis selanjutnya, merupakan kelanjutan dari analisis nonlinier pada tahapan sebelumnya. Maksud dari pernyataan ini yaitu gaya-gaya dalam, lendutan dan retak penampang pada tahap sebelumnya diikutsertakan pada analisis tahap berikutnya. Pada penelitian ini retak penampang tidak diperhitungkan. Dalam analisis konstruksi bertahap, hasil analisis pada tahap terakhirlah yang akan digunakan sebagai acuan.

\section{METODE PENELITIAN}

Pada tahap awal penelitian, akan dilakukan pemodelan struktur rangka terbuka 3, 4 dan 5 lantai dengan ketentuan SNI 1726:2002. Model struktur RT dua dimensi 3, 4 dan 5 lantai tersebut terdiri dari tiga bentang dengan panjang bentang $6 \mathrm{~m}$ dan tinggi tingkat $3,5 \mathrm{~m}$ (Gambar 2), dirancang sesuai pendetailan biasa/menengah yang pada program didefinisikan sebagai sway ordinary. Untuk struktur utama digunakan beton dengan kuat tekan puncak $\left(f^{\prime}{ }_{c}\right) 25 \mathrm{MPa}$ dan modulus elastisitas $\left(E_{c}\right)$ 19.230,185 MPa. Digunakan tulangan dengan tegangan leleh $\left(f_{y}\right) 320 \mathrm{Mpa}$ dan tegangan putus $\left(f_{u}\right) 400 \mathrm{Mpa}$. Setelah mendapatkan dimensi struktur berdasarkan SNI 1726:2002, kemudian dianalisis kembali dengan ketentuan SNI 1726:2012 dengan pendetailan khusus yang pada program didefinisikan sebagai sway special .
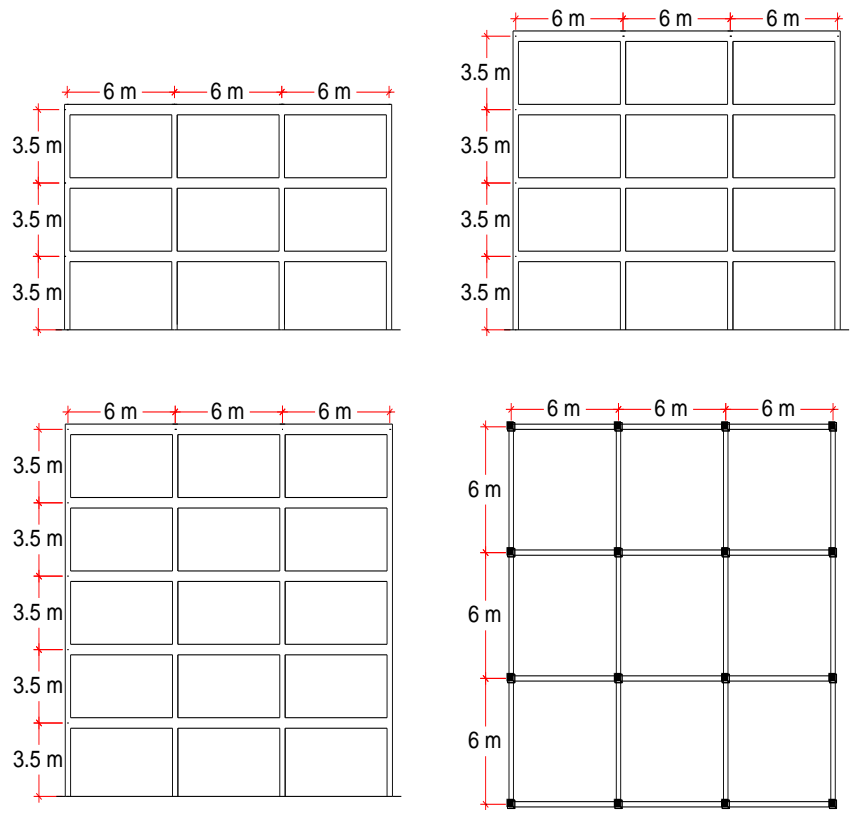

Gambar 2. Struktur Rangka Terbuka (RT) 3, 4 dan 5 Tingkat 
Struktur rangka terbuka yang telah dianalisi dengan ketentuan SNI 1726:2012, kemudian ditambahkan breising sebagai perkuatan seismik. Digunakan 2 tipe breising yaitu X dan V terbalik seperti pada Gambar 3. Breising dimodel sebagai elemen frame dan pemodelan breising hanya dibuat pada bagian tengah bentang. Breising menggunakan profil IWF 200.200.49,9. Digunakan material baja BJ 41 dengan tegangan leleh $\left(f_{y}\right) 250 \mathrm{Mpa}$ dan tegangan putus $\left(f_{u}\right) 410 \mathrm{Mpa}$.

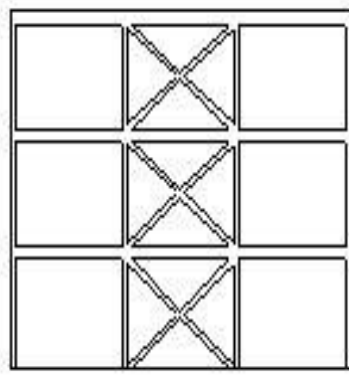

(a) Tipe $\mathrm{X}$

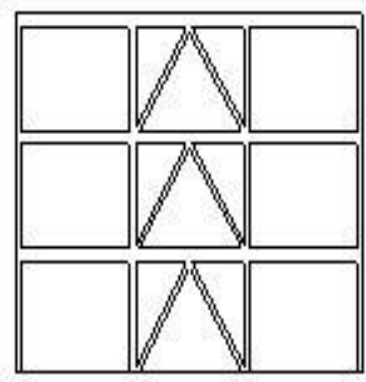

(b) Tipe V Terbalik
Gambar 3. Variasi Tipe Breising untuk Masing-masing Tingkat

Beban-beban yang bekerja pada struktur terdiri dari beban mati, hidup dan gempa. Beban mati terdiri dari berat sendiri struktur (dihitung secara otomatis oleh program SAP2000) dan beban mati tambahan sebesar $160 \mathrm{~kg} / \mathrm{m}^{2}$. Beban hidup terdiri dari beban hidup lantai sebesar $250 \mathrm{~kg} / \mathrm{m}^{2}$ dan atap sebesar $100 \mathrm{~kg} / \mathrm{m}^{2}$. Dalam mendefinisikan beban gempa, pada program digunakan pengaturan Auto Lateral Load berdasarkan aturan UBC 97 untuk peraturan gempa SNI 1726:2002 dan IBC 2009 untuk peraturan gempa SNI 1726:2012. Struktur rangka terbuka dengan perkuatan breising tersebut, selain dianalisis dengan analisis konvensional juga akan dianalisis sesuai tahapan pelaksanaannya yaitu analisis konstruksi bertahap (stage construction analysis).

Analisis konstruksi bertahap ini terdiri dari 3 tahap seperti pada Gambar 4. Tahap 1 terdiri dari struktur rangka terbuka tanpa perkuatan breising. Kondisi awal adalah sama dengan nol, yaitu kondisi dimana struktur belum dibebani. Beban-beban yang bekerja pada struktur adalah beban mati yaitu berat sendiri struktur dan beban mati tambahan serta beban hidup. Pada tahap 2, struktur rangka terbuka diperkuat dengan penambahan breising. Kondisi awal adalah lanjutan dari kondisi akhir tahap 1. Beban-beban yang bekerja pada struktur adalah beban mati yaitu berat sendiri breising. Sedangkan pada tahap 3, struktur rangka terbuka dengan perkuatan breising dibebani dengan beban gempa sesuai SNI 1726:2012. Kondisi awal adalah lanjutan dari kondisi akhir tahap 2. Beban-beban yang bekerja pada struktur adalah beban mati yaitu berat sendiri struktur dan beban mati tambahan, beban hidup serta beban gempa.

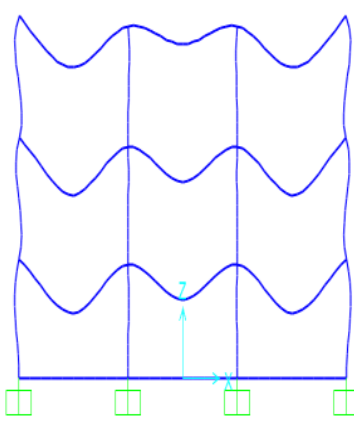

(a) Tahap 1

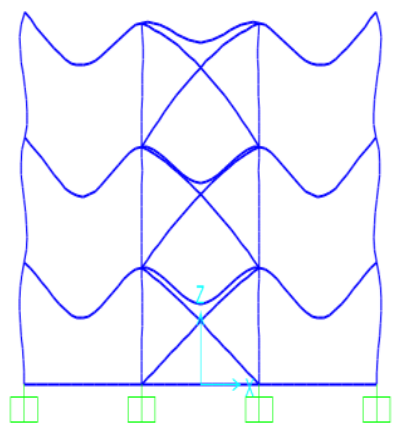

(b) Tahap 2
$(\mathrm{RT}+\operatorname{Beban}(\mathrm{D}+\mathrm{L})) \quad(\mathrm{RBX}+\mathrm{Beban}(\mathrm{D}+\mathrm{L}))$

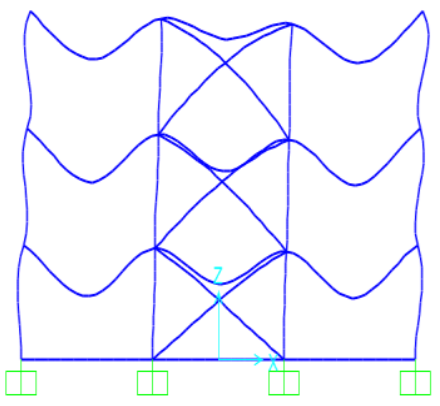

(a) Tahap 3

$(\mathrm{RBX}+$ Beban $(\mathrm{D}+\mathrm{L}+\mathrm{E}))$

Gambar 4. Analisis Konstruksi Bertahap Portal 3 Tingkat

\section{HASIL DAN PEMBAHASAN}

\section{Simpangan}

Dari model portal dengan tiga lantai yang berbeda didapat simpangan total pada tiap lantai seperti pada Gambar 5. Berdasarkan perbandingan simpangan dari semua model, terlihat bahwa struktur dengan perkuatan breising jauh memperkecil simpangan yang terjadi baik pada model 3, 4, dan 5 lantai. Dari analisis konstruksi bertahap, perkuatan dengan 
breising $\mathrm{X}$ mampu memperkecil simpangan dengan rasio masing-masing $0.08,0.12$ dan 0.18 untuk struktur 3,4 dan 5 lantai. Sedangkan perkuatan dengan breising V terbalik konsentrik memperkecil simpangan dengan rasio masing-masing $0.07,0.11$ dan 0.16 . Dengan analisis konstruksi bertahap simpangan struktur rangka breising $\mathrm{X}$ meningkat $14,38 \%, 13,62 \%$ dan $9,98 \%$ dari hasil analisis konvensional untuk struktur 3, 4 dan 5 lantai. Untuk struktur dengan breising V terbalik simpangan meningkat masing-masing $15,83 \%, 14,29 \%$ dan $10,09 \%$.

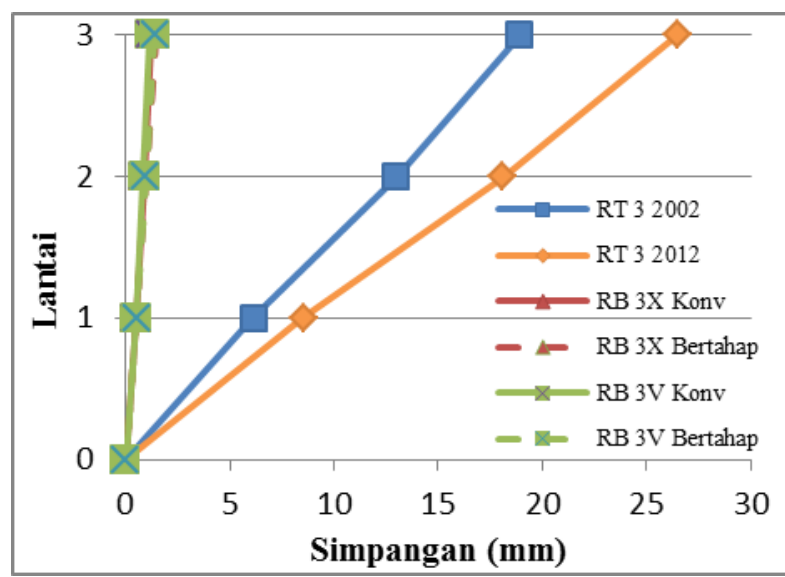

(a) Portal 3 Lantai

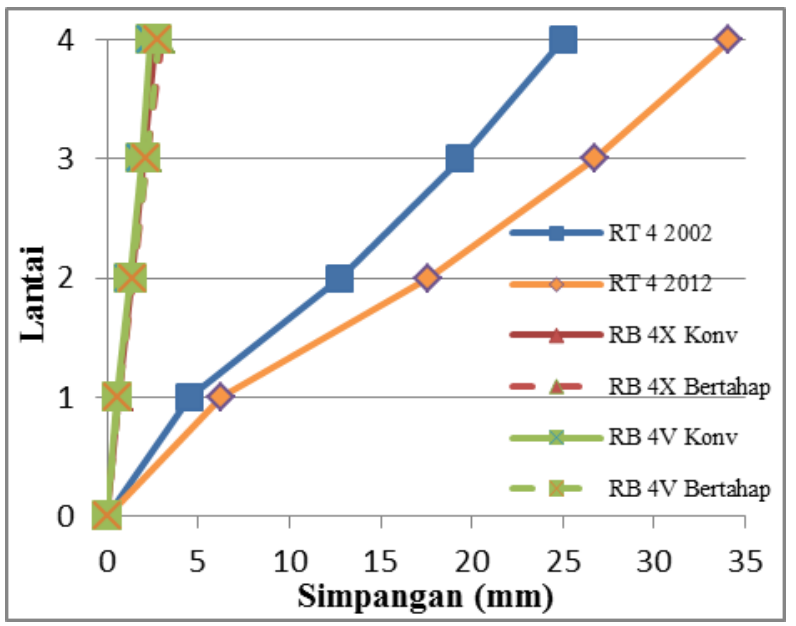

(b) Portal 4 Lantai

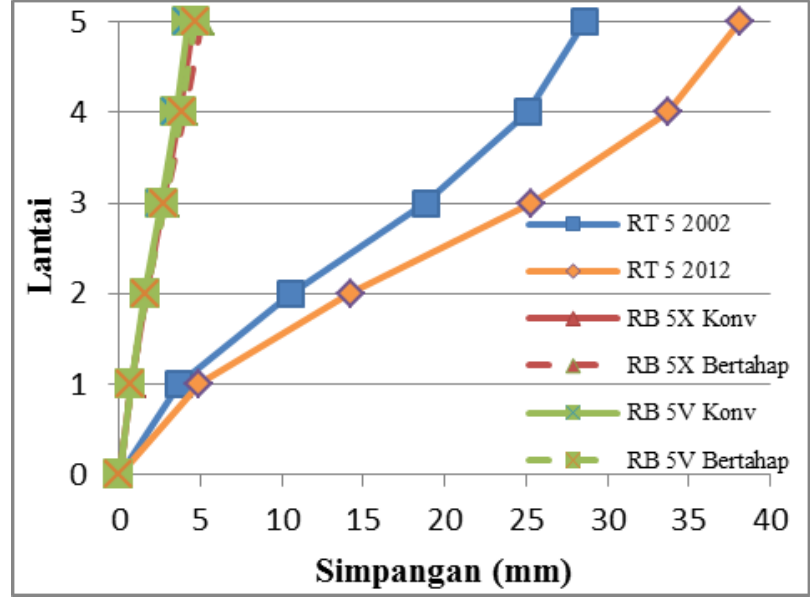

(c) Portal 5 Lantai

Gambar 5. Simpangan Total Tiap Lantai

Simpangan total yang terjadi pada setiap model juga dikontrol terhadap simpangan ijin sesuai persyaratan SNI 1726:2012 yaitu sebesar 0,02. $h_{\text {sx }}$ dengan $h_{s x}$ adalah tinggi tingkat. Untuk model 3 lantai dengan tinggi tingkat total $10.500 \mathrm{~mm}$ didapat simpangan ijin $210 \mathrm{~mm}$. Sedangkan untuk model 4 dan 5 lantai dengan tinggi total $14.000 \mathrm{~mm}$ dan $17.500 \mathrm{~mm}$ didapat simpangan ijin $280 \mathrm{~mm}$ dan $350 \mathrm{~mm}$. Simpangan total dari ketiga model tersebut sudah memenuhi ketentuan simpangan ijin.

Disamping simpangan total dari setiap model akan dibandingkan drift ratio (\%) yaitu perbandingan simpangan tiap tingkat dengan tinggi tingkat seperti pada Gambar 6.

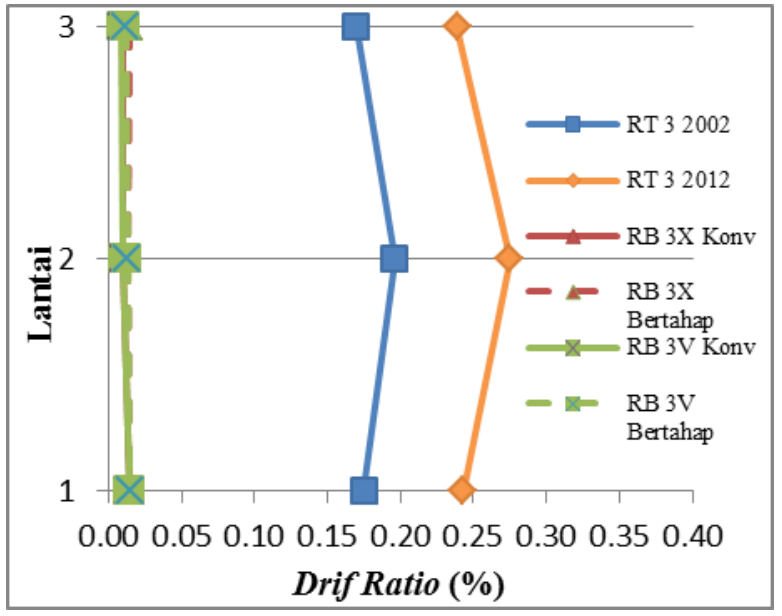

(a) Portal 3 Lantai 


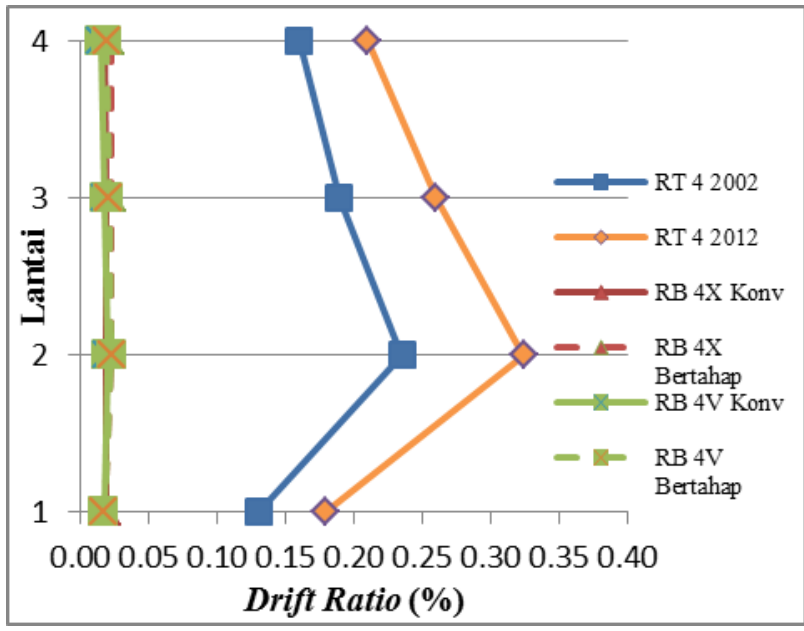

(b) Portal 4 Lantai

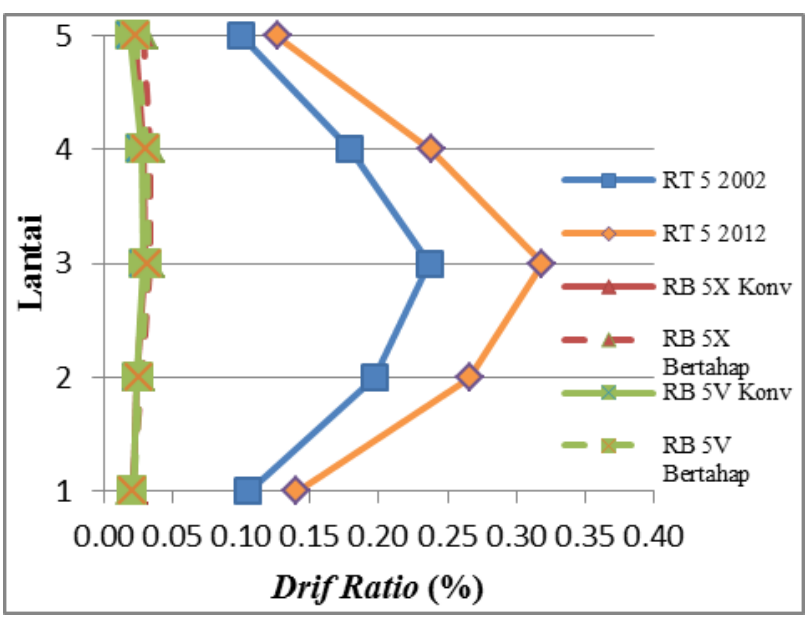

(c) Portal 5 Lantai

Gambar 6. Drift Ratio Tiap Lantai

Berdasarkan SNI 1726:2012 drift ratio maksimum tiap tingkat yaitu 0,02 (2\%). Berdasarkan Gambar 6, drift ratio tiap tingkat dari ketiga model tersebut sudah memenuhi ketentuan. Berdasarkan SNI 1726:2012 soft storey terjadi jika perbedaan kekakuan suatu tingkat dengan tingkat diatasnya lebih besar dari $30 \%$. Berdasarkan gambar 6, soft storey terjadi pada model rangka terbuka 4 dan 5 lantai. Pada model 4 lantai soft storey terjadi pada lantai 1 dengan perbedaan kekauan 80,70 $\%$ dengan tingkat diatasnya. Sedangkan pada model 5 lantai soft storey terjadi pada lantai 1 dan lantai 4 dengan perbedaan kekauan 88,90 $\%$ dan $45,71 \%$ dengan tingkat diatasnya. Untuk model dengan breising $\mathrm{X}$ soft storey terjadi pada lantai 1 dengan tingkat diatasnya pada model 3, 4 dan 5 lantai dengan perbedaan kekakuan 35,19\%, 38,98\% dan 32,86\%. Sedangkan untuk model dengan breising $\mathrm{V}$ terbalik tidak terjadi soft storey.

\section{Gaya-gaya Dalam}

Penambahan breising pada struktur rangka terbuka berpengaruh terhadap gayagaya dalam yang terjadi pada balok dan kolom. Penambahan breising pada struktur rangka terbuka sebagai perkuatan mampu memperkecil momen dan gaya geser yang terjadi pada balok dan kolom. Sedangkan gaya normal yang terjadi pada kolom meningkat. Perkuatan struktur rangka terbuka dengan breising $\mathrm{X}$ yang dianalisis dengan metode konstruksi bertahap, mampu memperkecil gaya-gaya dalam pada balok sampai $15,12 \%$, $14,49 \%$ dan $15,27 \%$ untuk struktur 3, 4 dan 5 lantai. Sedangkan perkuatan struktur rangka terbuka dengan breising $\mathrm{V}$ terbalik memperkecil gaya-gaya dalam sampai 15,40 $\%, 15,06 \%$ dan $15,85 \%$. Gaya-gaya dalam pada balok yang dianalisis dengan metode analisis konstruksi bertahap, 0,03\%, 0,29\% dan $0,28 \%$ lebih besar dibandingka dengan nilai-nilai pada analisis konvensional untuk struktur 3, 4 dan 5 lantai dengan breising X. Sedangkan pada struktur dengan breising $\mathrm{V}$ terbalik, gaya-gaya dalam pada balok hasil analisis metode konstruksi bertahap 8,01\%, $8,03 \%$ dan $7,02 \%$ lebih besar dibandingkan nilai-nilai hasil analisis metode konvensional.

Perkuatan breising tipe $\mathrm{X}$ pada struktur rangka terbuka yang dianalisis dengan metode konstruksi bertahap, mampu memperkecil momen dan gaya geser pada kolom sampai $27,99 \%, 24,04 \%$ dan 29,34\% untuk struktur 3, 4 dan 5 lantai. Sedangkan perkuatan struktur dengan breising $\mathrm{V}$ terbalik memperkecil momen dan gaya geser sampai 28,32 \%, 24,87 $\%$ dan 29,64 \%. Terjadi peningkatan gaya normal pada struktur rangka terbuka yang diperkuat dengan breising. Pada struktur dengan breising $\mathrm{X}$ gaya normal meningkat $17,18 \%, 21,16 \%$ dan $24,15 \%$ untuk struktur 3, 4 dan 5 lantai. Sedangkan pada struktur dengan breising $\mathrm{V}$ terbalik gaya normal meningkat $12,64 \%, 17,35 \%$ dan $20,95 \%$. 
Gaya-gaya dalam kolom analisis konstruksi bertahap lebih besar daripada nilai-nilai pada analisis konvensional.

\section{Perbandingan Luas Tulangan}

Luas tulangan kolom meningkat 11,03\%, $7,32 \%$ dan $4,84 \%$ untuk struktur 3, 4 dan 5 lantai dan tulangan balok meningkat $1,10 \%$, $2,19 \%$ dan $2,52 \%$ jika didesain dengan beban gempa sesuai dengan SNI 1726:2012. Struktur rangka terbuka tersebut kemudian diperkuat dengan sistem breising dan dibandingakan luas tulangannya dengan luas tulangan terpasang sesuai beban gempa SNI 1726:2002. Dari hasil analisis didapat bahwa, struktur dengan perkuatan breising dapat memperkecil luas tulangan perlu.

Pada analisis konstruksi bertahap, persentase penurunan luas tulangan balok dan kolom antara perkuatan dengan breising $\mathrm{X}$ dan $\mathrm{V}$ terbalik relatif sama. Luas tulangan kolom rata-rata menurun $7,91 \%, 7,49 \%$ dan $5,29 \%$ untuk struktur 3, 4 dan 5 lantai dengan breising $X$. Sedangkan untuk struktur dengan breising $\mathrm{V}$ terbalik tulangan kolom rata-rata menurun 7,93\%, 7,52 \% dan 5,31\%. Untuk struktur 3, 4 dan 5 lantai, tulangan balok ratarata menurun $17,76 \%, 18,80 \%$ dan $20,67 \%$ untuk struktur dengan breising $X$ serta 18,78 $\%, 18,79 \%$ dan $20,65 \%$ untuk struktur dengan breising $\mathrm{V}$ terbalik.

Pada analisis konvensional, luas tulangan kolom rata-rata menurun 8,21\%, 7,67 \% dan $5,42 \%$ untuk struktur 3, 4 dan 5 lantai dengan breising $X$. Sedangkan pada struktur dengan breising $\mathrm{V}$ terbalik, tulangan kolom rata-rata menurun $5,14 \%, 4,79 \%$ dan 3,92\%. Pada struktur dengan breising $\mathrm{V}$ terbalik, penurunan luas tulangan balok jauh lebih besar daripada breising $\mathrm{X}$. Tulangan balok menurun $35,35 \%$, $36,78 \%$ dan $39,16 \%$ untuk struktur 3,4 dan 5 lantai dengan breising $\mathrm{V}$ terbalik. Untuk struktur dengan breising $\mathrm{X}$, tulangan balok rata-rata hanya menurun $0,02 \%, 0,12 \%$ dan $0,73 \%$.

Disamping penurunan luas tulangan, juga terjadi peningkatan yang cukup kecil pada luas tulangan daerah lapangan balok. Tetapi jika diasumsikan jumlah tulangan terpasang pada daerah lapangan balok, didapat jumlah tulangan yang sama antara kondisi awal dengan kondisi setelah diperkuat dengan breising. Untuk struktur 3, 4 dan 5 lantai, tulangan balok rata-rata meningkat $0,28 \%$, $0,38 \%$ dan $0,43 \%$ untuk struktur dengan breising $X$ serta $2,76 \%, 2,53 \%$ dan 2,16\% untuk struktur dengan breising $\mathrm{V}$ terbalik.

\section{SIMPULAN DAN SARAN Simpulan}

Perkuatan struktur dengan breising pada analisis konvensional maupun bertahap memperkecil simpangan lateral struktur. Metode analisis konstruksi bertahap menghasilkan hasil analisis berupa simpangan, gaya-gaya dalam dan luas tulangan yang lebih besar dari hasil analisis konvensional.

Pada analisis konstruksi bertahap, perkuatan dengan breising $\mathrm{X}$ mampu memperkecil simpangan dengan rasio masingmasing $0.08,0.12$ dan 0.18 untuk struktur 3,4 dan 5 lantai. Sedangkan perkuatan dengan breising $\mathrm{V}$ terbalik konsentrik memperkecil simpangan dengan rasio masing-masing 0.07 , 0.11 dan 0.16. untuk struktur 3, 4 dan 5 lantai.

Dengan analisis konstruksi bertahap simpangan struktur rangka breising $\mathrm{X}$ meningkat $14,38 \%, 13,62 \%$ dan $9,98 \%$ dari hasil analisis konvensional untuk struktur 3, 4 dan 5 lantai. Untuk struktur dengan breising $\mathrm{V}$ terbalik simpangan meningkat masing-masing 15,83\%, 14,29 $\%$ dan $10,09 \%$.

Perkuatan struktur dengan breising pada struktur 3, 4 dan 5 lantai menurunkan momen dan gaya geser pada balok dan kolom, sedangkan gaya normal meningkat. Perkuatan struktur dengan breising juga menyebabkan terjadinya penurunan luas tulangan balok dan kolom.

\section{Saran}

Analisis struktur dengan perkuatan, sebaiknya menggunakan analisis konstruksi bertahap, karena memberikan hasil yang lebih sesuai dengan kondisi lapangan. Disamping itu, perlu adanya penelitian lebih lanjut mengenai perkuatan struktur dengan breising pada model gedung dan jumlah lantai yang berbeda.

\section{UCAPAN TERIMA KASIH}

Dalam penyelesaian penelitian ini penulis mengucapkan terima kasih kepada Program Magister Teknik Sipil Universitas Udayana 
yang telah mendanai penelitian ini beserta semua pihak yang telah membantu penulis.

\section{DAFTAR PUSTAKA}

AISC, ANSI/ASCE 341-10. 2010. Seismic Provisions for Structural Steel Buildings. American Institute of Steel Construction, Chicago.

BSN. 2002. Tata Cara Perencanan Struktur Baja untuk Bangunan Gedung SNI 031729-2002. Badan Standarisasi Negara, Jakarta.

BSN. 2002. Standar Perencanaan Ketahanan Gempa Untuk Struktur Bangunan Gedung SNI 1726:2002. Badan Standarisasi Negara, Jakarta.

BSN. 2012. Perencanaan Ketahanan Gempa Untuk Struktur Bangunan Gedung dan Non Gedung SNI 1726:2012. Badan Standarisasi Negara, Jakarta.

BSN. 2013. Persyaratan Beton Struktural untuk Bangunan Gedung SNI 2847:2013. Badan Standarisasi Negara, Jakarta

Computers and Structures, Inc. 2002. Analysis Reference SAP2000.

Ismail dkk. 2015. "Analisa Perkuatan (Retrofitting) Gedung STKIP ADZKIA Padang dengan Menggunakan Breising Baja". Prosiding Seminar Nasional Teknik Sipil 1 (SeNaTS), Sanur-Bali.

Maheri, M.R. 2009. "Internal Steel Braces of RC Frames". $3^{\text {rd }}$ International Conference on Concrete \& Development, Tehran, Iran.

Massumi, A. and Absalan, A. 2013. "Interaction Between Braces System and Moment Resisting Frame in Braced Frame". Archives of Civil and Mechanical Engineering, Vol. 13, 260-268.

Massumi, A. and Tasnimi, A.A. 2008. "Strengthening of Low Ductile Reinforced Concrete Frames Using Steel X-Braces with Different Details".
Proceedings of the Fourteen World Conference on Earthquake Engineering (14WCEE), Beijing, China.

Nawy, E.G. 2009. Prestressed Concrete Fifth Edition Upgrade: ACI, AASHTO, IBC 2009 Codes Version.. Pearson Education Inc.

Smith, B.S. and Coull, A. 1991. Tall Building Structures; Analysis and Design. John Wiley and Sons Inc.

Viswanath, K.G, Prakash, K.B and Anant, D. 2010. "Seismic Analysis of Steel Braced Reinforced Concrete Frames". International Jurnal of Civil and Structure Engineering, Vol. 1 (1), 114122.

Youssef, M. A., H. Ghaffarzadeh, et al. (2007). "Seismic performance of $\mathrm{RC}$ frames with concentric internal steel bracing." Engineering Structures 29(7): 1561-1568. 